\title{
Histological and Ultrastructural Analysis of Spermatogenesis in Gelastocoris flavus flavus (Heteroptera: Nepomorpha) \\ Alevi KCC ${ }^{*}$, Pereira LLV ${ }^{1}$, Moreira FFF³, Barbosa $\mathrm{JF}^{4}$, Taboga $\mathrm{SR}^{5}$ and Itoyama MM
}

${ }^{1}$ Laboratório de Citogenética e Molecular de Insetos, Instituto de Biociências, Letras e Ciências Exatas - Universidade Estadual Paulista "Júlio de Mesquita Filho" (IBILCE/UNESP), São José do Rio Preto, SP, Brasil

${ }^{2}$ Laboratório de Biologia Celular, Instituto de Biociências, Letras e Ciências Exatas - Universidade Estadual Paulista "Júlio de Mesquita Filho" (IBILCE/UNESP), São José do Rio Preto, SP, Brasil

${ }^{3}$ Laboratório Nacional e Internacional de Referência em Taxonomia de Triatomíneos, Fundação Oswaldo Cruz (FIOCRUZ), Rio de Janeiro, RJ, Brasil

${ }^{4}$ Laboratório de Entomologia, Universidade Federal do Rio de Janeiro (UFRJ), Rio de Janeiro, RJ, Brasil

"Laboratório de Microscopia e Microanálise, Instituto de Biociências, Letras e Ciências Exatas - Universidade Estadual Paulista "Júlio de Mesquita Filho" (IBILCEI UNESP), São José do Rio Preto, SP, Brasil

\begin{abstract}
Studies on the ultrastructural aspects of spermatogenesis and, specifically, the structure of sperm in aquatic Heteroptera are scarce. Therefore, the objective of this study was to analyse of the histology and ultrastructure of spermatogenesis. Semi-fine sections of the testicles of adult male Gelastocoris flavus flavus were stained with toluidine blue or impregnated with silver ions, and ultra-fine sections were analysed by transmission electron microscopy. The ultrastructural features observed during spermatogenesis of the species showed the presence of several small mitochondria uniformly distributed in the cytoplasm of cells in prophase I. These mitochondria then came together to form fewer, larger structures, which converged and formed the mitochondrial complex. Later, this mitochondrial complex was divided into two structures, termed mitochondrial derivatives, which were arranged bilaterally to the axoneme. The axoneme showed a flagellar pattern of 9+9+2. A vesicle was observed that originated in the early stages of spermiogenesis and was composed of many argyrophilic granules that united to form a single structure. This vesicle contained some highly stained structures in its interior. Thus, this paper describes histological and ultrastructural characteristics during spermatogenesis, contributing to the reproductive knowledge of these aquatic Heteroptera.
\end{abstract}

Keywords: Argyrophilic granules; Mitochondrial derivative; Axoneme; Nucleolus

\section{Introduction}

In both vertebrates and invertebrates, studies addressing the ultrastructural aspects of spermatogenesis and, specifically, the structure of the sperm comprise a vast and growing body of literature. In insects, the study of the ultrastructural aspects of spermiogenesis and sperm began in the 1970s, when the methods for electron microscopy of biological material were optimised [1-3], but in Heteroptera, studies are still scarce. Some ultrastructures involved in spermatogenesis, such as the acrosome, axoneme, mitochondria and chromatoid body, are described in the literature.

In most species, the acrosome (Ac) is an organelle essential for fecundation [1]. In addition to fecundation, the acrosome is also related to the sperm's ability to remove the protective mechanism on the surface of ovule and/or to digest barriers to the migration of sperm into the female reproductive tract [4]. Acrosomes originate from the Golgi complex [5,6].

Research on the structural organisation of the axoneme $(\mathrm{Ax})$ has received valuable contributions from numerous observations made in the sperm flagellum of Drosophila [7-9]. In most insects, the organisational pattern of the axoneme follows the pattern $9+9+2$, which is the usual arrangement of $9+2$ microtubules surrounded by nine additional accessory microtubules $[1,2,10]$. In some mosquitoes, the pattern $9+9+1$ is common, whereas in mayflies, the pattern $9+9+0$ predominates [1]. There are also patterns that are considered aberrant; for example, in dipterous of the Cecidomyiidae family, the schema is $13+0[11]$.

Another ultrastructure often analysed during spermatogenesis is the mitochondria, which assume different morphologies. In insects, the regularity in the mitochondrial shape is particularly notable [1]. During spermatogenesis, the mitochondria undergo metamorphosis, where the typical structure of mitochondria is completely modified. In the initial stages of differentiation, a complex fusion process occurs, and mitochondria rearrange, forming the mitochondrial complex. This complex is often termed "Nebenkern," especially in older studies $[1,2,12-14]$. As spermatogenesis continues, the mitochondrial complex divides into two mitochondrial derivatives (MD), which are positioned bilaterally to the axoneme during the spermatozoid stretching process [15].

During differentiation, the mitochondrial derivatives are filled along their length by a protein structure that is organised in a paracrystalline pattern, and many species of insects accumulate these structures in mitochondria during spermiogenesis $[1,10,16,17]$. This paracrystalline structure is also known as a crystalloid and is formed by a protein rich in proline [18]. In Heteroptera (Pentatomidae, Reduviidae and Gerridae family), two or three crystalline bodies within the mitochondrial derivatives have been observed [19].

Various functions have been suggested for the mitochondrial

*Corresponding author: Alevi KCC, Instituto de Biociências, Letras e Ciências Exatas, IBILCE - UNESP. Rua Cristovão Colombo, 2265 Jardim Nazareth 15054 000 - São José do Rio Preto, SP - Brasil, Tel: (17) 32212380 extn. 2378; Email: kaiochaboli@hotmail.com

Received July 22, 2015; Accepted July 26, 2015; Published July 28, 2015

Citation: Alevi KCC, Pereira LLV, Moreira FFF, Barbosa JF, Taboga SR, et al (2015) Histological and Ultrastructural Analysis of Spermatogenesis in Gelastocoris flavus flavus (Heteroptera: Nepomorpha). Entomol Ornithol Herpetol 4: 157. doi:10.4172/2161-0983.1000157

Copyright: (c) 2015 Alevi KCC, et al. This is an open-access article distributed under the terms of the Creative Commons Attribution License, which permits unrestricted use, distribution, and reproduction in any medium, provided the original author and source are credited. 
Citation: Alevi KCC, Pereira LLV, Moreira FFF, Barbosa JF, Taboga SR, et al. (2015) Histological and Ultrastructural Analysis of Spermatogenesis in Gelastocoris flavus flavus (Heteroptera: Nepomorpha). Entomol Ornithol Herpetol 4: 157. doi:10.4172/2161-0983.1000157

derivatives of sperm in insects; for example, they may participate in the control and regulation of flagellar movement or shape, or they may be involved in the storage and release of the energy required for flagellar motility [5,20,21]. However, Perotti [22] contradicted this last statement, relating the mitochondrial derivatives to paternal cytoplasmic inheritance and presuming that the material stored in the MDs may be involved in the activation and nutrition of the oocyte after fertilisation.

In addition to the structures mentioned previously, the cytoplasm of germ cells contains a build-up of a material termed a chromatoid body (CB) or "nuage" [23]. The CB is a macromolecular complex that is thought to play a coordinating role in the post-transcriptional control of gene products in haploid male germ cells and also to function as a centre for the determination of mRNA [23-25].

Some authors believe that the $\mathrm{CB}$ originates from a material between clusters of mitochondria that is present in the cytoplasm of germinal cells [26]. However, more recent studies describe the origin as coming from the fragmentation of nucleolar material during the process of spermatogenesis [27-34]. Other structures that have been studied are the nucleolus and other structures that are impregnated with silver ions. The size of the nucleolus is related to the biosynthetic activity of the cell; therefore, the size and number of nucleoli and pre-nucleolar bodies depend on the metabolic and functional characteristics of the cells [35-42].

In most species of arthropods, the nucleoli dissociate at the diplotene stage or diakinesis. Therefore, the corpuscles impregnated by the Ag-NOR technique, which are specific proteins associated with rRNA, are not visible from metaphase to telophase I. These markings reappear at the beginning of spermatid formation, indicating that the transcriptional functions of ribosomal RNA have resumed, and they finally disappear at the end of spermatid formation [43,44]. However, the literature reports some exceptions; for example, in Asellus aquaticus (Isopoda) and species of the genus Rhodnius (Hemiptera), Ag-NOR corpuscles were visualised during the entire process of spermatogenesis [42,43]; in Callicrania seoanei (Orthoptera), Ag-NORs were observed in interkinesis until pro-metaphase II [45]; and in Triatoma infestans and T. sordida (Hemiptera), the markings were present until metaphase I [35]. Furthermore, in Carlisis wahlbergi (Heteroptera, Coreidae), nucleolar semi-persistence (the presence of nucleolar corpuscles during metaphase) was observed until metaphase II [46], whereas for Acanthocoris sordidus (Heteroptera, Coreidae) and Coptosoma punctissimum (Heteroptera, Plataspidae), the nucleoli were detected in metaphase plates of primary and secondary spermatocytes [47].

With the objective of broadening the information known histological and ultrastructural about aquatic Heteroptera spermatogenesis, we analysed the species Gelastocoris flavus flavus.

\section{Material and Methods}

Testicles of G.f. flavus males were extracted and immediately fixed in Karnovsky fixative solution for a period of 3 to 48 hours. Samples were then washed twice in Millonig buffer, and post-fixation was performed with Osmium Tetroxide 1\% Millonig (1:3) for 2 hours in a refrigerator. The material was washed thoroughly with bidistilled water and then dehydrated in a series of solutions with increasing concentrations of acetone until a concentration of $100 \%$ was reached. A pre-infiltration in araldite: acetone (1:1) was performed overnight at room temperature. Afterwards, infiltration in araldite was performed for 2 hours at $37^{\circ} \mathrm{C}$ and was then continued for 48 hours at $60^{\circ} \mathrm{C}$. Semifine and ultra-fine sections were obtained using a Leica Ultracut UCT ultramicrotome. The semi-fine sections were stained with toluidine blue pH4.0 [48] or silver ions (Ag-NOR) (Howell and Black [49], with modifications). The ultra-fine sections were collected on grids and then contrasted with $2 \%$ uranyl acetate for 20 minutes [50], followed by $2 \%$ lead citrate solution with $1 \mathrm{~N}$ sodium hydroxide for 6 minutes [51]. The results of transmission electron microscopy were documented by electron micrographs obtained from a CM100 Philips transmission electron microscope at the Center of Electron Microscopy, Institute of Biosciences, Botucatu, UNESP - IBB Campus Botucatu. São Paulo, Brazil.

\section{Results}

The images obtained from semi-fine sections and ultramicrographs showed several rounded chromatoid bodies (CBs) with different sizes in prophase I (Figures 1a, 2a and $2 \mathrm{~b}$ ). These were located near pore complexes of the nuclear envelope (Figure $2 \mathrm{~d}$ and 2e). Small mitochondria were also observed that were uniformly dispersed within the cytoplasm (Figures 1a and 2a-c). The mitochondria were starting to come together to form larger structures (Figure 1c) and were moving to one side of the cell (Figures 1c-1e and 2c), forming the mitochondrial complex (MC). The MC is a unique structure in that it is rounded and contains a tangle of mitochondria (Figure $1 \mathrm{~h}$ and 1i). During the elongation of spermatids, the MC was divided in two sections, forming the Mitochondrial Derivatives (MDs), which were initially very close to each other and bilaterally flanked the axoneme (Ax) (Figures 1l, $2 \mathrm{f}$ and $2 \mathrm{~g}$ ). In a later stage, the MDs separated, with the Ax between them (Figures $1 \mathrm{n}-\mathrm{p}$ and $2 \mathrm{f}-\mathrm{i}$ ). At the end of the process, the MDs completely surrounded the Ax (Figure $2 \mathrm{j}$ ). A crystalloid structure was also seen in the interior of the MDs (Figure $2 \mathrm{f}$ and $2 \mathrm{~g}$ ). In Figure $2 \mathrm{k}$,

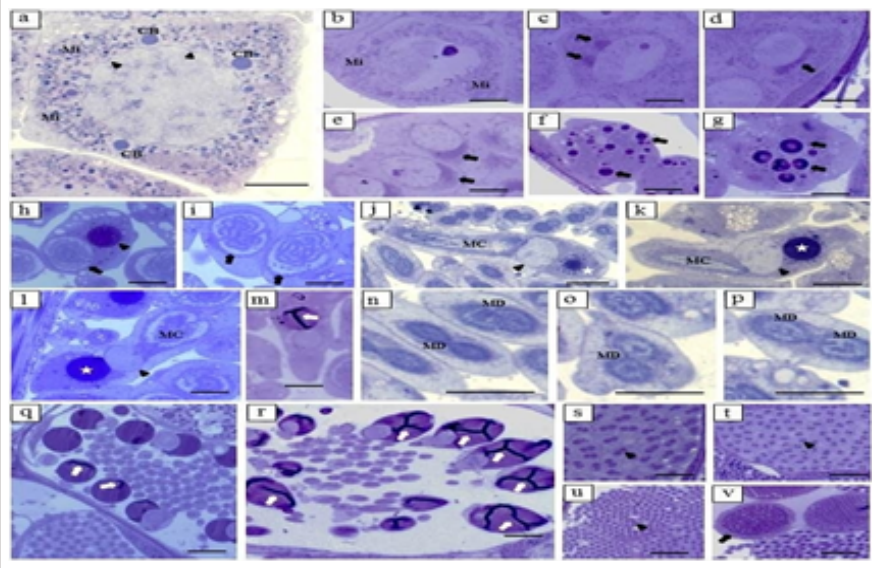

Figure 1: Semi-fine sections of Gelastocoris flavus flavus testicle stained with toluidine blue. a) Prophase I, showing the chromatoid bodies (CB) rounded, of varying sizes and with sharp metachromasia. Near the CB are pore complexes (arrowheads) and mitochondria (Mi); b-c) mitochondrial complex formation; in "b", mitochondria (Mi) are small, isolated and dispersed throughout the cytoplasm. In " $c$ ", mitochondria are beginning to unite on one side of the cell (arrows); d,e) mitochondrial complex formation (arrows); f-g) early spermatids with several argyrophilic granules of different sizes (arrows); h) union of argyrophilic granules forming a vesicle (arrowhead) and the mitochondrial complex (arrow); i) spermatids with the mitochondrial complex (arrows); $j-1)$ spermatids in elongation showing the mitochondrial complex (MC), a highly stained vesicle (asterisk) and a vesicle without staining (arrowhead); $\mathbf{m}$ ) vesicle containing a more intensely coloured region (arrow); $\mathbf{n}-\mathbf{p}$ ) cross-section of a tail showing the mitochondrial derivative (MD); q-r) longitudinal section of the head, containing a vesicle with more highly stained interior regions (arrows); s-u) cross-section of different regions of the tail showing the mitochondrial derivative (arrowheads); v) cyst with spermatozoids (arrow). Bars: $10 \mu \mathrm{m}$. 

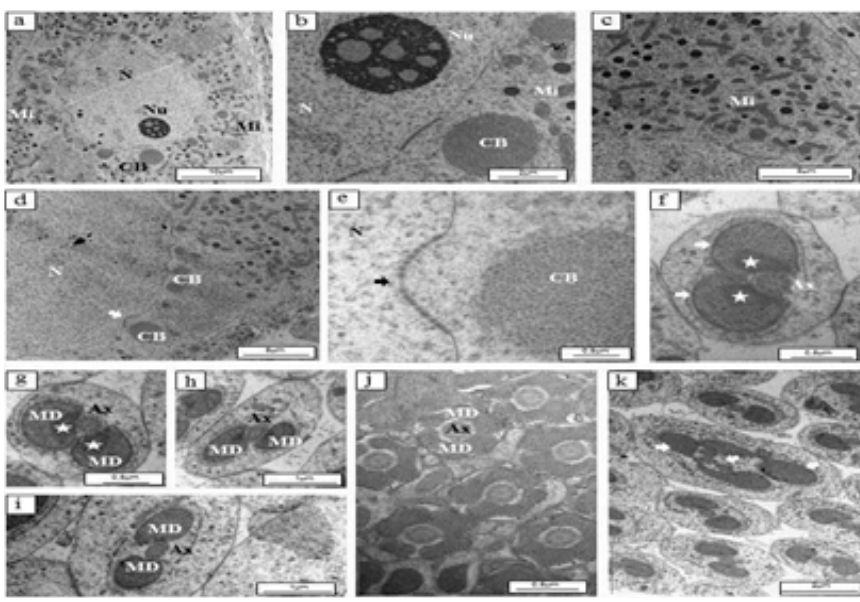

Figure 2: Electron micrographs of Gelastocoris flavus flavus testicular cells. a) Cell in prophase I showing the nucleolus $(\mathrm{Nu})$, which is more electrodense than the other structures and has less electrodense interior regions (this region, in more detail, can be viewed in b); a-c) mitochondria (Mi) of different sizes and enlargements. Note that in "c", mitochondria are primarily located on one side of the cell, $\mathrm{CB}$ : chromatoid body, $\mathrm{N}$ : nucleus, Nu: nucleolus; d,e) the chromatoid body (CB) and the pore complex (arrows). In "e", these structures are shown at a higher magnification; f) cross section of tail, showing the mitochondrial derivatives (arrows) and the presence of interior crystalloids (asterisks) and the axoneme (Ax); $\mathbf{g}-\mathrm{j}$ ) tail formation process in relation to the mitochondrial derivative (MD) and the axoneme (Ax). In " $\mathrm{g}$ ", the mitochondrial derivatives are close, and the axoneme is still moving to the central region of the tail; note the presence of crystalloids (asterisks); j) axoneme surrounded by the mitochondrial derivative; $\mathbf{k}$ ) supernumerary elements (arrows). Bars: $10 \mu \mathrm{m}$

supernumerary elements were observed (the presence of four Ax and two mitochondrial derivatives in the same tail). Another structure observed in the cell nucleus at prophase I was the nucleolus (Figure $2 \mathrm{a}$ and $2 \mathrm{~b}$ ), which was rounded and more electrodense than the other structures, with less electrodense interior regions. As shown in Figure $3 \mathrm{a}$ and $3 \mathrm{~b}$, a cell in prophase I was also observed with various markings that were silver-positive, small, rounded and dispersed throughout the cytoplasm. In the early stages of spermiogenesis, many argyrophilic granules could be seen that were strongly coloured and of different sizes (Figure $1 \mathrm{f}$ and $\mathrm{lg}$ ). They began to unite into a single vesicle, which was rounded and heavily stained (Figure $1 \mathrm{~h}, \mathrm{k}$ ). In cells impregnated with silver ions, rounded structures of different sizes were observed; the structures united and formed a single structure that was also rounded and located adjacent to the MC (Figure 3c-h). Observation of the silver-impregnated sections revealed a more highly impregnated region inside the vesicle (Figure 3h-3m). As shown in Figures 1q, 1r and 3n, o longitudinal sections of the spermatid head were observed and showed the vesicle with markings. Toluidine blue staining indicated that the interior of the vesicle contained intensely stained filaments with an irregular morphology (Figure $1 \mathrm{~m}$ and $1 \mathrm{r}$ ). The organisational pattern of the axoneme was verified by transmission electron microscopy to have the $9+9+2$ pattern (Figure 2j). As shown in Figure 1s-v, cysts containing sperms at different stages of development were observed.

\section{Discussion}

The literature regarding the ultrastructural aspects of Heteroptera spermatogenesis is extremely limited, yet understanding these aspects is of fundamental importance, because some structures cannot be analysed with light microscopy. In the species analysed in this study, argyrophilic granules were observed both by toluidine blue staining and by silver ion markings. These granules were present in the cytoplasm of prophase I and spermatids, and the granules came together to form a vesicle. Because these structures have not been described in other aquatic Heteroptera, more studies are necessary to determine the contents of these granules and their function. The vesicles observed in spermatids are most likely the nucleus and acrosome; however, it was not possible to determine the position of these structures in spermatids with the techniques used here. Further studies should be performed to determine accurate positions of the mentioned structures, both in spermatids and in sperm of G. f. flavus.

The acrosome, for example, was analysed in Gerris najas (Gerridae) [52], Notonecta glauca (Notonectidae) [53] and Euchistus heros [54], and it was observed that acrosome vesicles were formed from the Golgi complex. Changes in the form and degree of chromatin condensation were also observed. Initially, chromatin was dispersed and had a low electrodensity, but during the course of spermatogenesis, the chromatin assumed a compact fibril arrangement and developed a high electrodensity.

Acrosome enzymes are usually stored as proenzymes and are released and activated when the acrosome reaction occurs, thus participating in the event of fertilisation [55-58]. Souza and Itoyama et al. [59] analyzed the acromosomogensis in six species of Heteroptera, by means of Periodic Acid Schiff (PAS) and have found that, in general, the behavior of periodic acid Schiff-positive granules for all of the species analyzed is similar. In the beginning of spermiogenesis, there is a central granule that migrates to one of the extremities of the spermatid, and later, it becomes elongated and cannot be distinguished in the spermatozoa.

CBs of G. f. flavus were observed near the pore complexes of the nuclear envelope. This observation agrees with recent work in various species showing that CBs originate from the fragmentation of nucleolar material, such as, for example, in observations by Comings and Okada [27] and Andonov [29] in rats, by Anderson (1978) in the blue fox, by

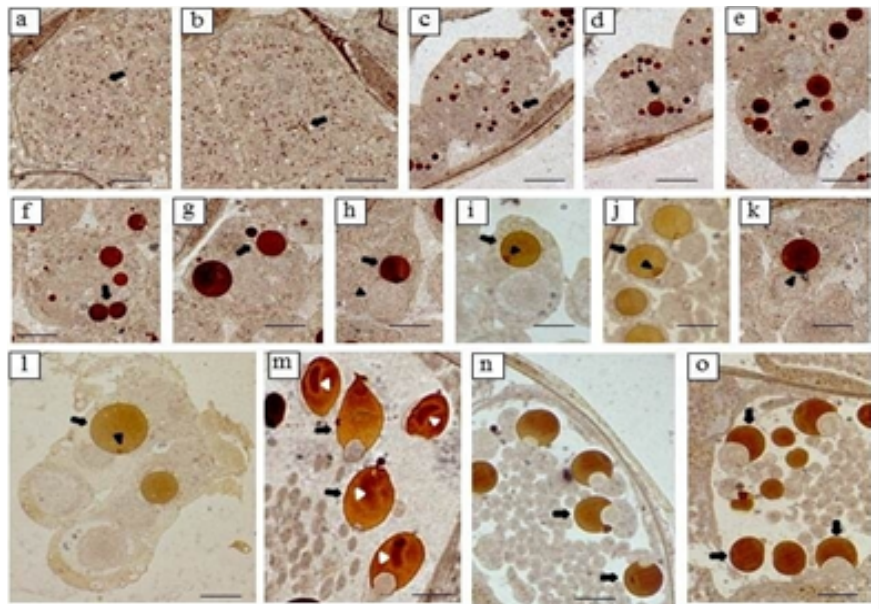

Figure 3: Semi-fine sections of Gelastocoris flavus flavus testicle impregnated with silver ions. $\mathbf{a}, \mathbf{b})$ Prophase I with several positive silver markings (arrows); c-e) spermatids with several silver-positive argyrophilic granules (arrows); $\mathbf{f , g}$ ) spermatids showing silver-positive argyrophilic granules uniting and forming larger and rounded vesicles (arrows); h) spermatid with a silver-positive vesicle (arrow) and the mitochondrial complex (arrowhead); i-m) silverpositive vesicle (arrows) with stronger interior staining, which internalises with spermatid elongation (arrowheads); $\mathbf{n}, \mathbf{0}$ ) longitudinal section of the head of the spermatids, with a silver-positive vesicle (arrows). Bars: $10 \mu \mathrm{m}$ 
Citation: Alevi KCC, Pereira LLV, Moreira FFF, Barbosa JF, Taboga SR, et al. (2015) Histological and Ultrastructural Analysis of Spermatogenesis in Gelastocoris flavus flavus (Heteroptera: Nepomorpha). Entomol Ornithol Herpetol 4: 157. doi:10.4172/2161-0983.1000157

Page 4 of 6

Peruquetti et al. [30-32] in Rattus novergicus, Mus musculus, gerbils and amphibians, and in triatomines by Silistino-Souza et al. [34].

Initial analysis of CB in Hemiptera hematophagous suggest that the formation of this organelle starts in spermatocytogenesis [60]. Furthermore, the authors suggest that the nucleolar persistence phenomenon observed in these insects is essential for CB formation, which presents extreme importance during the spermiogenesis these vectors, since during this phase of spermatogenesis the nucleolus shows no transcriptional activity [61].

Regarding the axoneme, the flagellar pattern observed for G. $f$. flavus was $9+9+2$ ( 9 accessories, 9 doublets and 2 central microtubules). Araujo et al. $[19,62]$ observed that for some species of the Pentatomidae and Largidae family, the flagellum consists of an axoneme and two mitochondrial derivatives, and the axoneme follows a microtubule arrangement pattern of $9+9+2$. This pattern was also described for other species of Heteroptera: Pentatomidae [63,64], Reduviidae [65,66], aquatic Heteroptera [67-69], Leptopodomorpha [70], Cimicomorpha, Gerromorpha, and Pentatomomorpha $[19,71]$ and is thus the default for this suborder.

It is known that insect mutants may exhibit disorders in spermiogenesis [72,73] and that ambient conditions such as temperature, humidity and food availability may influence the normal process of spermiogenesis $[74,75]$. The presence of aberrant spermatids in insect spermiogenesis does not appear to be a rare event. Caetano [76], for example, described Atta capigura and A. sexdens rubropilosa (Formicidae) sperm with supernumerary elements. The supernumerary elements found in the G. f. flavus species may be caused by possible stress during collection, by the condition of the environment where they were collected or due to natural occurrence. However, more study is necessary to conclusively determine why occurs supernumerary elements during spermatogenesis.

Thus, this paper describes histological and ultrastructural characteristics during spermatogenesis, contributing to the reproductive knowledge of these aquatic Heteroptera.

\section{Acknowledgments}

We thank Me. Luiz Roberto Falleiros Júnior and Dr. Rosana Silistino de Souza from the Biology Department of IBILCE/UNESP for orientation and assistance with ultrastructural analysis and FAPESP, CNPq, and FUNDUNESP for financial support.

\section{References}

1. Phillips DM (1970) Insect sperm: their structure and morphogenesis. J Cell Biol 44: 243-277.

2. Baccetti B (1972) Insect sperm cell. Adv in Insect Phys 9: 315-397.

3. Messias JR (1990) Aspectos Ultra-Estruturais da espermiogênese de Crysomya megacephala Fab (Diptera: Calliphoridae). Dissertação. Universidade Estadual de Campinas. Campinas, São Paulo, Brasil.

4. Fawcett DW, Ito S (1965) The Fine structure of bat permatozoa. Am J Anat 116: 567-609.

5. Yasuzumi G (1974) Electron microscope studies on spermiogenesis in various animal species. Int Rev Cytol 37: 53-119.

6. Báo SN, Quagio-Grassiotto I, Dolder H (1989) Acrosome formation in Ceratitis capitata (Diptera, Tephritidae). Cytobios 58: 93-100.

7. Perotti ME (1969) Ultrastructure of the mature sperm of Drosophila melanogaster Meig. J Submicrosc Cytol 1: 171-196.

8. Kiefer RG (1970) Development, organization and degeneration of the Drosophila sperm flagellum. J Cell Sci 6: 177-194.

9. Dallai R, Afzelius BA (1991) Sperm flagellum of Dacus oleae (Gmelin)
(Tephritidae) and Drosophila melanogaster (Drosophilidae) (Diptera). Int J Insect Morphol Embryol 20: 215-222.

10. Warner FD (1971) Spermatid differentiation in the blowfly Sarcophaga bullata with particular reference to flagellar morphogenesis. J Ultrastruct Res 35: 210 232

11. Baccetti B, Dallai R (1976) The spermatozoan of arthropoda. XXVII. Uncommon axoneme patterns in different species of the cecidomyid flies. J Ultrast Res 55 $50-69$

12. Pratt $S$ (1970) Formation and differentiation of the Nebenkern in spermatios of na hemipteran insect, Murgantia iristionia. In: Baccetti B (edn.) Comparative Spermatology, Academic Press, London, pp 301-310.

13. Tandler B, Hoppel C (1972) Mitochondria in spermatogenesis. In: Tandle B, Hoppel C (eds.) Mitochondria, (1stedn.), Academic Press, New York and London, pp. 2: 36-39.

14. Baccetti B, Afzelius BA (1976) The biology of the sperm cell. Monogr Dev Biol $1-254$

15. Tokuyasu KT (1974) Dynamics of spermiogenesis in Drosophila melanogaster 3. Relation between axoneme and mitochondrial derivatives. Exp Cell Res 84 239-250.

16. Rosati F, Selmi G, Mazzini M (1976) Comparative observation on the mitochondrial derivatives of insect sperm. J Submicrosc Cytol 8: 56-67.

17. Báo SN, Lins U, Farina B, de Souza W (1992) Mitochondrial derivatives of Culex quinquefasciatus (Culicidae) spermatozoon: Some new aspects evidenced by cytochemistry and image processing. J Struct Biol 109: 46-51.

18. Baccetti B, Dallai R, Pallini V, Rosati F, Afzelius BA (1977) Protein of insect sperm mitochondrial crystals. Crystallomitin. J Cell Biol 73: 594-600.

19. Araújo VA, Lino-Neto J, de Sousa Ramalho F, Zanuncio JC, Serrão JE (2011) Ultrastructure and heteromorphism of spermatozoa in five species of bugs (Pentatomidae: Heteroptera). Micron 42: 560-567.

20. Phillips DM (1974) Structural variants in invertebrate sperm flagella and their relationship to motility. In: Sleigh MA (eds) Cilia and Flagella, Academic Press, London, pp. 2: 379-402.

21. Tokuyasu KT (1975) Dynamics of spermiogenesis in Drosophila melanogaster V. Head-tail alignment. J Ultrastruct Res 50: 117-129.

22. Perotti ME (1973) The mitochondrial derivative of the spermatozoon of Drosophila before and after fertilization. J Ultrastruct Res 44: 181-198.

23. Parvinen $\mathrm{M}$ (2005) The chromatoid body in spermatogenesis. Int J Androl 28 : 189-201.

24. Kotaja N, Bhattacharyya SN, Jaskiewicz L, Kimmins S, Parvinen M, et al (2006) The chromatoid body of male germ cells: similarity with processing bodies and presence of Dicer and microRNA pathway components. Proc Nat Acad Sci U S A 103: 2647-2652.

25. Kotaja N, Sassone-Corsi $P$ (2007) The chromatoid body: a germ-cell-specific RNA-processing centre. Nat Rev Mol Cell Biol 8: 85-90.

6. Fawcett DW, Eddy EM, Phillips DM (1970) Observations on the fine structure and relationships of the chromatoid body in mammalian spermatogenesis. Bio Reprod 2: 129-153.

27. Comings DE, Okada TA (1972) The chromatoid body in mouse spermatogenesis: evidence that it may be formed by the extrusion of nucleolar components. J Ultrastruct Res 39: 15-23.

28. Andersen K (1978) Fine structure of spermatogonia and spermatocytes in the blue fox (Alopex lagopus). Acta Vet Scand 19: 229-242.

29. Andonov M (1990) Further study of the chromatoid body in rat spermatocytes and spermatids. Z Mikrosk Anat Forsch 104: 46-54.

30. Peruquetti RL, Assis IM, Taboga SR, Azeredo-Oliveira MTV (2008) Meiotic nucleolar cycle and chromatoid body formation during the rat (Rattus novergicus) and mouse (Mus musculus) spermiogenesis. Micron 39: 419-425.

31. Peruquetti RL, Taboga SR, de Azeredo-Oliveira MT (2010) Characterization of Mongolian gerbil chromatoid bodies and their correlation with nucleolar cycle during spermatogenesis. Reprod Domest Anim 45: 399-406.

32. Peruquetti RL, Taboga SR, Santos LRS, Oliveira C, Azeredo-Oliveira MTV (2011) Nucleolar cycle and chromatoid body formation: Is there a relationship 
Citation: Alevi KCC, Pereira LLV, Moreira FFF, Barbosa JF, Taboga SR, et al. (2015) Histological and Ultrastructural Analysis of Spermatogenesis in Gelastocoris flavus flavus (Heteroptera: Nepomorpha). Entomol Ornithol Herpetol 4: 157. doi:10.4172/2161-0983.1000157

between these two processes during spermatogenesis of Dendropsophus minutus (Amphibia, Anura)? Micron 42: 87-96

33. Morielle-Souza A, Taboga SR, de Azeredo-Oliveira MT (2010) Ultrastructural analysis of the nucleolar aspects at spermiogenesis in triatomines (Heteroptera, Triatominae). Micron 41: 791-796.

34. Silistino-Souza R, Peruquetti RL, Taboga SR, Vilela de Azeredo-Oliveira MT (2012) Chromatoid body: remnants of nucleolar proteins during spermatogenesis in triatomine (Heteroptera, Triatominae). Micron 43: 954-960.

35. Tavares MG, Azeredo-Oliveira MJV (1997) Pattern of nucleolar activity during spermatogenesis in triatomines (Heteroptera: Reduviidae) as analysed by silver staining. Cytobios 89: 93-103.

36. Souza HV, Bicudo HEMC, Costa LAA, Itoyama MM (2007) A study of meiosis and spermatogenesis in different testicular lobes of Antiteuchus tripterus (Heteroptera, Pentatomidae). Eur J Ent 104: 353-362.

37. Souza HV, Bicudo HE, Itoyama MM (2007) Study of chromosomal and nucleolar aspects in testes of Nysius californicus (Heteroptera: Lygaeidae). Genet Mol Res 6: 33-40.

38. Castanhole MMU, Pereira LLV, Souza HV, Bicudo HEMC, Costa LAA et al. (2008) Heteropicnotic chromatin and nucleolar activity in meiosis and spermiogenesis of Limnogonus aduncus (Heteroptera, Gerridae): a marked RON revealing aspect of the chromosomal behavior. Gen Mol Res 7: 13981407.

39. Castanhole MM, Pereira LL, Souza HV, Itoyama MM (2010) Spermatogenesis and karyotypes of three species of water striders (Gerridae, Heteroptera). Genet Mol Res 9: 1343-1356.

40. Castanhole MM, Pereira LL, de Souza HV, Itoyama MM (2012) Spermatogenesis of riffle bugs, Rhagovelia whitei and Rhagovelia sp (Veliidae), and backswimmers Martarega sp (Notonectidae). Genet Mol Res 11: $2003-2020$

41. Alevi KCC, Mendonça PP, Pereira NP, Rosa JA, Azeredo-Oliveira MTV (2013b) Análise das Regiões Organizadoras Nucleolares e da atividade nucleolar em Triatoma melanocephala e T. lenti, importantes vetores da doença de Chagas. Rev Cienc Farm Básica e Aplicada 34: 417-21

42. Alevi KC, da Costa Castro NF, Lima AC, Ravazi A, Morielle-Souza A, et al (2014) Nucleolar persistence during spermatogenesis of the genus Rhodnius (Hemiptera, Triatominae). Cell Biol Int 38: 977-980.

43. Bressa MJ, Papeschi AG, Fumagalli E, van Doesburg PH, Larramendy ML (2003) Cytogenetic and nucleolar meiotic cycle analyses in Dysdercus imitator Blöte, 1931 (Pyrrhocoridae, Heteroptera) from Argentina. Folia Biol (Krakow) 51: 135-141.

44. Di Castro M, Prantera G, Cipriani L, Rocchi A (1983) Silver staining analysis of nucleolar-organizer activity during spermatogenesis of Asellus aquaticus (Crustacea, Isopoda). Genetica 60: 163-166

45. Santos J, Sentis C, Fernandez-Piqueras J (1987) Pattern of nucleolar organizer region activity during male meiosis in Callicrania seoanei (Orthoptera) as analyzed by silver staining: evidences for a possible reactivation in the period between the two meiotic divisions. Genome 29: 516-518.

46. Fossey A, Liebenberg $H$ (1995) Meiosis and nucleolar structures in the stink bug Cartisis wahlbergi Stal (Coreidae: Heteroptera). Cytobios 81: 7-15.

47. Yoshida, T (1947) Unusual type of the nucleolus observed in a bug Acanthocoris sordidus. J Fac Sci 9: 243-249.

48. Mello MLS, Vidal BC (1980) Práticas de Biologia Celular. FUNCAMP Editora Edgard Blücher LTDA, Campinas, São Paulo, Brasil.

49. Howell WM, Black DA (1980) Controlled silver-staining of nucleolus organize regions with a protective colloidal developer: a 1-step method. Experientia 36 1014-1015.

50. Watson ML (1958) Staining of tissue sections for electron microscopy with heavy metals. J Biophys Biochem Cytol 4: 475-478.

51. Venable JH, Coggeshall $R$ (1965) A simplified lead citrate stain for use in electron microscopy. J Cell Biol 25: 407-408.

52. Werner G, Werner K (1993) Changes in the nucleus, endoplasmic reticulum, Golgi apparatus, and acrosome during spermiogenesis in the waterstrider Gerris najas deg. (Heteroptera: Gerridae). Int J Insect Morphol Embryol 22 $521-534$
53. Werner G, Afzelius BA, Mosler B (1988) Acrosome formation during spermiogenesis in Notonecta glauca L. (Heteroptera). J Submicrosc Cyto Pathol 20: 123-135.

54. Fernandes AP, Curi G, França FG, Báo SN (2001) Nuclear changes and acrosome formation during spermiogenesis in Euchistus heros (Hemiptera: Pentatomidae). Tissue Cell 33: 286-293.

55. Yanagimachi R (1988) Mammalian fertilization. In: Knobil, E and Neill, J (ed) The Physiology of Reproduction (1st edn.) Raven Press, New York, pp. 2: 135185.

56. Baccetti B, Burrini AG, Collodel G, Piomboni P, Renieri T, et al. (1989) Localization of acrosomal enzymes in Arthropoda, Echinodermata and Vertebrata. J Submicrosc Cytol Pathol 21: 385-389.

57. Tesarik J, Drahorad J, Testart J, Mendoza C (1990) Acrosin activation follows its surface exposure and precedes membrane fusion in human sperm acrosome reaction. Development 110: 391-400.

58. Gallo JM, Escalier D, Grellier P, Précigout E, Albert M, et al. (1991) Characterization of a monoclonal antibody to human proacrosin and its use in acrosomal status evaluation. J Histochem Cytochem 39: 273-282.

59. Souza HV, Itoyama MM (2010) Study of acrosome formation, interspecific and intraspecific, in the testicular lobes of some pentatomid species. J Insect Sci 10: 132

60. Borgueti AO, Alevi KCC, Silistino-Souza R, Rosa JA, Azeredo-Oliveira (2015) Immunofluorescence and ultrastructural analysis of the chromatoid body during spermatogenesis of Triatoma platensis and T. rubrovaria (Hemiptera, Triatominae). Micron 74: 44-46.

61. Alevi KCC, Mendonça PP, Pereira NP, Rosa JA, Azeredo-Oliveira. Is there post-meiotic transcriptional activity during hemipteran spermiogenesis? Inv Rep Dev 58: 193-198.

62. Araújo VA, Báo SN, Lino-Neto J (2012) Polymorphism of spermatozoa in Largus rufipennis Laporte 1832 (Heteroptera: Pyrrhocoroidea: Largidae). Acta Zoologica 93: 239-244

63. Trandaburu V (1973) The acrosome and the centriole adjunct in Eurydema ventralis Kol. (Heteroptra, Pentatomidae). Trav Mus Nat Hist Nat Grig Antipa 13: $137-145$

64. Fernandes AP, Báo SN (1998) Spermiogenesis in phytophagous bug (Hemiptera, Pentatomidae): an ultrastructural study. J Submicrosc Cytol Patho 30: 485-493.

65. Dolder H (1988) Cytoskeletal bridges between organelles in sperm?agellum of Triatoma infestans (Hemiptera, Reduviidae). J Ultrast Mol Struct Res 101 159-164.

66. Báo SN, de Souza W (1994) Structural specialization in the flagellum of the spermatozoon of the bloodsucking bug (Rhodnius prolixus; Hemiptera, Reduviidae). Tissue Cell 26: 299-308.

67. Afzelius BA, Dallai R, Lindskog P (1985) Spermatozoa of saldid bugs (Insecta Hemiptera, Leptopodomorpha). J Ultrast Res 90: 304-312.

68. Lee CE (1991) Morphological and phylogenetic studies on the true water bugs (Hemiptera: Heteroptera). J Nat Hist Soc Korea 21: 1-183.

69. Lee YH, Lee CE (1992) Ultrastructure of spermatozoa and spermatogenesis in Nepomorpha (Insecta: Heteroptera) with special reference to phylogeny. Zoo Sci 9: 971-981.

70. Afzelius BA, Baccetti B, Dallai R (1976) The giant spermatozoon of Notonecta. J Submic Cytol Pathol 8: 149-161.

71. Dallai R, Afzelius BA (1980) Characteristics of the sperm structure in Heteroptera (Hemiptera, Insecta). J Morphol 164: 301-309.

72. Báo SN (1987) Estudo ultra-estrutural da espermiogênese no mutante "olhoróseo" comparativo a linhagem selvagem de Ceratitis capitata Weidmann (Diptera, Tephritidae). Dissertação. Universidade Estadual de Campinas, Campinas, São Paulo, Brasil.

73. Báo SN, Dolder J (1991) Abnormal characteristics observed in spermatic cells during spermiogenesis in the Ra mutant of Ceratitis capitata (Diptera, Tephritidae). Rev Bras Gen 14: 287-297.

74. Szöllösi A (1976) Influence of infra-optimal breeding temperature on spermiogenesis of the locust Locusta migratoria. I. Abnormalities in differentiation of the cytoplasmic organelles. J Ultrastruct Res 54: 202-214. 
Citation: Alevi KCC, Pereira LLV, Moreira FFF, Barbosa JF, Taboga SR, et al. (2015) Histological and Ultrastructural Analysis of Spermatogenesis in Gelastocoris flavus flavus (Heteroptera: Nepomorpha). Entomol Ornithol Herpetol 4: 157. doi:10.4172/2161-0983.1000157

Page 6 of 6

75. Szöllösi A (1976) Influence of infra-optimal breeding temperature on spermiogenesis of the locust Locusta migratoria. II. Abnormalities in differentiation of the nucleus. J Ultrastruct Res 54: 215-223.
76. Caetano FH (1980) Ultraestrutura dos espermatozóides de Atta capiguara e Atta sexdens rubropilosa (Formicidae). Naturalia 5: 105-111.
Citation: Alevi KCC, Pereira LLV, Moreira FFF, Barbosa JF, Taboga SR, et al. (2015) Histological and Ultrastructural Analysis of Spermatogenesis in Gelastocoris flavus flavus (Heteroptera: Nepomorpha). Entomol Ornithol Herpetol 4: 157. doi:10.4172/2161-0983.1000157
Submit your next manuscript and get advantages of OMICS Group submissions

Unique features:

- User friendly/feasible website-translation of your paper to 50 world's leading languages

Audio Version of published paper

- Digital articles to share and explore

Special features:

- 400 Open Access Journals

- 30,000 editorial team

21 days rapid review process

Quality and quick editorial, review and publication processing

Indexing at PubMed (partial), Scopus, EBSCO, Index Copernicus and Google Scholar etc

- Sharing Option: Social Networking Enabled

- Authors, Reviewers and Editors rewarded with online Scientific Credits

- Better discount for your subsequent articles

Submit your manuscript at: www.omicsonline.org/submission/ 